\title{
MECHANISMS CONTRIBUTING TO UNRESPONSIVENESS TO MERCURIAL DIURETICS IN CONGESTIVE FAILURE ${ }^{1,2}$
}

\author{
BY RAYMOND E. WESTON, DORIS J. W. ESCHER, ${ }^{3}$ JACOB GROSSMAN, AND \\ LOUIS LEITER
}

(From the Medical Division, Montefiore Hospital, New York, N. Y.)

(Submitted for publication July 11, 1952; accepted August 1, 1952)

The ultimate failure of edematous cardiac patients to respond to mercurial diuretics is well established. Although the older literature ascribed this to renal tubular accommodation to mercury, some patients have received mercurials for many years without manifesting such acquired tubular resistance. More recently, because of the potentiation of mercurial diuresis in previously unresponsive patients by pre-treatment with ammonium chloride, resistance to mercurials has been attributed to chloride depletion $(1,2)$. However, acidotic potentiation of mercurial diuresis may persist after the elevated serum chloride level has returned to normal (3). Moreover, mercurial-resistant patients may not exhibit hypochloremia and some hypochloremic patients continue to have good mercurial diureses (2).

Since organic mercurials act by decreasing renal tubular reabsorption of filtered electrolyte and water, any factor which increases such reabsorption will tend to antagonize the diuretic effect of mercurials. The present communication is an attempt to analyze mercurial resistance in cardiac patients in the light of the severely impaired renal excretion of salt and water, resulting from the changes in cardiovascular-renal hemodynamics, hormonal balance, and other mechanisms affecting renal tubular activity in congestive failure.

One of these factors, decreased glomerular filtration rate, reduces the quantity of filtered sodium and chloride presented to the tubules. Recent studies have shown that whenever filtration is decreased without change in tubular function the resulting glomerulo-tubular imbalance is associ-

${ }_{1}^{1}$ Supported in part by grants from the National Heart Institute, U. S. Public Health Service; Martha Hall Foundation, Montefiore Hospital ; Campbell Pharmaceutical Co.; Eli Lilly \& Company; Wyeth, Inc.; and G. D. Searle \& Co.

2 Presented in part at II Inter-American Cardiological Congress, Chicago, 1948.

8 Rosenstock Memorial Fellow, 1947-1949. ated with a more complete reabsorption of sodium $(4,5,6,7)$. Thus, late in congestive failure, the progressive impairment of glomerular filtration may finally so diminish the quantity of electrolyte filtered that virtually all of the sodium reaching the tubules is reabsorbed; consequently, negligible diuresis results even after depression of tubular activity by the usual dose of a mercurial.

This relationship between the electrolyte load delivered to the tubules and the response to mercurials was evaluated in a series of mercurial-resistant subjects by studying the influence on mercurial diuresis of measures which increase the quantity of sodium filtered. The results suggest that a reduced filtered load of electrolyte, as well as other factors, may contribute to the state of mercurial resistance.

\section{METHODS AND MATERIALS}

The subjects were nine edematous and one edema-free cardiac patients, maintained on a low salt diet, who were no longer responsive to mercurials despite adequate digitalization, bed rest, and pre-treatment with ammonium chloride. Seven were patients with rheumatic heart disease, uncomplicated by known renal disease. Two were patients with arteriosclerotic heart disease. One (J. B.) was an edema-free, digitalized, young hypertensive, in whom a marked drop in filtration rate and renal plasma flow had been produced during a six-week period on the rice diet with repeated administration of mercurial diuretics until no further response was elicited (8).

With the resting patients in the post-absorptive state, renal clearances of mannitol and sodium para-aminohippurate, and urinary outputs and serum concentrations of sodium and chloride were determined, before and after achieving a maximal response to a $2 \mathrm{ml}$. intravenous injection of either Mercuzanthin or Thiomerin. Immediately thereafter, an effort was made to increase the quantity of filtered sodium, either by the intravenous administration of $0.72 \mathrm{gm}$. of theophylline ethylene diamine (aminophyllin), or the rapid infusion of a concentrated sodium chloride solution or a sodium chloride-sodium lactate mixture. All the determinations then were repeated. The clearance techniques and chemical methods 
TABLE I

Typical diuretic response to Mercuzanthin in patient $K . B$. with moderate impairment of renal hemodynamics

\begin{tabular}{|c|c|c|c|c|c|c|c|c|c|}
\hline Period & R.P.F. & G.F.R. & $\underset{\mathrm{Na}}{\text { Serum }}$ & $\underset{\mathrm{Cl}}{\text { Serum }}$ & $\begin{array}{l}\text { Na } \\
\text { filt. }\end{array}$ & $\underset{\text { excr. }}{\mathrm{Na}}$ & $\begin{array}{c}\mathrm{Cl} \\
\text { filt. }\end{array}$ & $\underset{\text { excr. }}{\mathrm{Cl}}$ & $\begin{array}{l}\text { Urine } \\
\text { vol. }\end{array}$ \\
\hline Control & $\begin{array}{c}\text { ml. } / \min . \\
221\end{array}$ & $\begin{array}{c}\text { ml. } . / \min \\
81.6\end{array}$ & $\begin{array}{c}m E q . / l . \\
133\end{array}$ & $\begin{array}{c}m E q . / l . \\
99.2\end{array}$ & $\begin{array}{c}m E q . / m i n . \\
10.9\end{array}$ & $\begin{array}{c}m E q . / m i n \\
0.002\end{array}$ & $\begin{array}{c}m E q . / m i n \\
9.03\end{array}$ & $\begin{array}{c}\text { mEq./min. } \\
0.003\end{array}$ & $\begin{array}{c}\text { ml. } / \min . \\
1.09\end{array}$ \\
\hline Mercurial & 229 & 89.6 & 132 & 98.0 & 11.2 & 0.730 & 9.21 & 0.762 & 6.91 \\
\hline
\end{tabular}

employed have already been described (8). In two patients, the augmentation of mercurial diuresis by aminophyllin or by concentrated sodium infusions was studied in separate experiments at three and six week intervals, respectively. In one patient, aminophyllin was administered also after previous potentiation of mercurial diuresis by sodium chloride. Control experiments and other variations in experimental design are discussed below.

\section{RESULTS}

In the tables, unless otherwise indicated, renal hemodynamic and electrolyte and water excretion data for "control" periods represent averages of at least two 20 to 30 minute clearance periods before administration of the mercurial, whereas "mercurial" periods represent those of maximal diuretic response or, in the case of completely unresponsive patients, clearance periods 60 to 120 minutes after injection of the mercurial. The renal hemodynamic data are not corrected for body surface area.

In Table I, the typical changes in renal plasma flow, glomerular filtration rate, ${ }^{4}$ quantity of sodium and chloride filtered, ${ }^{5}$ and electrolyte and water excretion following intravenous injection of $2 \mathrm{ml}$.

4 Mannitol was used as an index of filtration rate when these experiments were performed. It has since been established that some reabsorption of this hexose does occur (9).

5 Calculated from serum electrolyte levels, corrected for Donnan equilibrium, in this and all succeeding tables.

TABLE II

Effect of the increased G.F.R. following aminophyllin injection on mercurial diuresis in mercurial resistant patients

\begin{tabular}{|c|c|c|c|c|c|c|c|c|c|c|}
\hline Patient & Period & R.P.F. & G.F.R. & $\underset{\mathrm{Na}}{\text { Serum }}$ & $\underset{\mathrm{Cl}}{\text { Serum }}$ & $\begin{array}{l}\mathrm{Na} \\
\text { filt. }\end{array}$ & $\underset{\text { excr. }}{\mathrm{Na}}$ & $\begin{array}{l}\mathrm{Cl} \\
\text { filt. }\end{array}$ & $\begin{array}{c}\mathrm{Cl} \\
\text { excr. }\end{array}$ & $\begin{array}{l}\text { Urine } \\
\text { vol. }\end{array}$ \\
\hline \multirow{3}{*}{ C. $\mathrm{R}$. } & Control & $\begin{array}{c}\text { ml./min. } \\
115\end{array}$ & $\begin{array}{c}\text { ml. } / \text { min } \\
41.1\end{array}$ & $\begin{array}{c}m E q . / l . \\
122\end{array}$ & $\begin{array}{c}m E q . / l . \\
84.3\end{array}$ & $\begin{array}{c}m E q . / m i n \\
5.01\end{array}$ & $\begin{array}{c}\text { mEq./min. } \\
0.002\end{array}$ & $\begin{array}{c}m E q . / \min . \\
3.82\end{array}$ & $\begin{array}{c}m E q . / m i n \\
0.004\end{array}$ & $\begin{array}{c}\text { ml. } / \text { min } \\
2.78\end{array}$ \\
\hline & Merc. & 99 & 36.1 & 120 & 84.6 & 4.32 & 0.005 & 3.37 & 0.021 & 1.86 \\
\hline & Aminoph. & 139 & 46.5 & 119 & 84.6 & 5.51 & 0.165 & 4.34 & 0.285 & 4.69 \\
\hline \multirow{3}{*}{ E. S. } & Control & 197 & 55.8 & 114 & 92.4 & 6.36 & 0.002 & 5.70 & 0.006 & 1.94 \\
\hline & Merc. & 164 & 46.4 & 112 & 88.7 & 5.20 & 0.026 & 4.59 & 0.050 & 2.23 \\
\hline & Aminoph. & 228 & 59.6 & 114 & 85.1 & 6.78 & 0.389 & 5.64 & 0.614 & 8.04 \\
\hline \multirow{3}{*}{ B. G. } & Control & 175 & 60.9 & 116 & 82.4 & 7.06 & 0.002 & 5.05 & 0.001 & 2.23 \\
\hline & Merc. & 148 & 56.0 & 120 & 81.5 & 6.75 & 0.003 & 4.43 & 0.002 & 1.94 \\
\hline & Aminoph. & 212 & 66.3 & 120 & 78.8 & 7.96 & 0.020 & 5.23 & 0.062 & 3.47 \\
\hline \multirow{3}{*}{ J. B. } & Control & 211 & 60.7 & 135 & 88.8 & 8.29 & 0.149 & 6.07 & 0.150 & 8.98 \\
\hline & Merc. & 188 & 53.2 & 137 & 90.1 & 7.49 & 0.199 & 5.38 & 0.216 & 5.44 \\
\hline & Aminoph. & 269 & 75.8 & 137 & 89.9 & 10.5 & 0.896 & 7.65 & 0.807 & 14.1 \\
\hline \multirow{3}{*}{ A. B. } & Control & 80 & 45.7 & 117 & 89.5 & 5.38 & 0.001 & 4.57 & 0.003 & 0.80 \\
\hline & Merc.* & 81 & 44.1 & 115 & 85.7 & 5.05 & 0.014 & 4.20 & 0.045 & 2.14 \\
\hline & Aminoph. & 115 & 61.0 & 115 & 85.4 & 7.00 & 0.227 & 5.76 & 0.371 & 7.11 \\
\hline
\end{tabular}

* Thiomerin $2 \mathrm{ml}$. The other patients received Mercuzanthin $2 \mathrm{ml}$. 
TABLE III

Comparison of effect of aminophyllin and Mercuzanthin plus aminophyllin in chronic congestive failure

\begin{tabular}{|c|c|c|c|c|c|c|c|c|c|c|}
\hline Patient & Period & R.P.F. & G.F.R. & $\underset{\mathrm{Na}}{\text { Serum }}$ & $\underset{\mathrm{Cl}}{\text { Serum }}$ & $\begin{array}{l}\mathrm{Na} \\
\text { filt. }\end{array}$ & $\begin{array}{c}\mathrm{Na} \\
\text { excr. }\end{array}$ & $\begin{array}{l}\mathrm{Cl} \\
\text { filt. }\end{array}$ & $\underset{\text { excr. }}{\mathrm{Cl}}$ & $\begin{array}{l}\text { Urine } \\
\text { vol. }\end{array}$ \\
\hline \multirow{2}{*}{ E. G. } & Control & $\stackrel{m l . / m i n}{-}$ & $\begin{array}{c}\text { ml. } / \text { min. } \\
65.0\end{array}$ & $\begin{array}{c}m E q . / l . \\
139\end{array}$ & $\begin{array}{c}m E q . / l . \\
-\end{array}$ & $\begin{array}{c}m E q . / m i n \\
8.99\end{array}$ & $\begin{array}{c}\text { mEq./min } \\
0.004\end{array}$ & $\stackrel{m E q . / m i n}{-}$ & mEq./min. & $\begin{array}{c}\text { ml. } / \min . \\
1.60\end{array}$ \\
\hline & Aminoph. & - & 90.0 & 142 & 一 & 12.8 & 0.020 & 一 & 一 & 4.37 \\
\hline \multirow{3}{*}{ H. G. } & Control & 247 & 71.2 & 132 & 91.8 & 9.49 & 0.009 & 7.34 & 0.031 & 1.44 \\
\hline & Merc. & 231 & 69.5 & 132 & 91.5 & 9.27 & 0.125 & 7.13 & 0.203 & 2.19 \\
\hline & Aminoph. & 347 & 90.4 & 132 & 89.1 & 12.0 & 0.738 & 9.00 & 0.939 & 7.45 \\
\hline
\end{tabular}

of Mercuzanthin in a mercurial-responsive patient (K. B.) are presented. This patient, whose glomerular filtration rate was only moderately decreased, excreted negligible quantities of sodium and chloride during the control periods but following the injection of the mercurial exhibited a marked sodium, chloride, and water diuresis. In contrast, patient C. R. (Table II), whose glomerular filtration rate and filtered electrolyte loads were markedly reduced, responded negligibly to this diuretic. However, when $0.72 \mathrm{gm}$. of aminophyllin were injected intravenously 90 minutes after the mercurial had been given, there was significant augmentation of filtration rate, renal plasma flow, and urinary excretion of sodium, chloride, and water.

In this laboratory, similar injections of aminophyllin alone generally have resulted in relatively small increases in the electrolyte excretion of patients in severe chronic congestive failure with functionally decreased renal hemodynamics. In Table III, such a response to aminophyllin alone in patient E. G. is compared with the response to aminophyllin following a mercurial in patient H. G., who had equivalent serum electrolyte levels and filtration rate. The latter exhibited only a moderate diuretic response to Mercuzanthin until $0.72 \mathrm{gm}$. of aminophyllin were injected. Then, with the marked increase in glomerular filtration rate and renal plasma flow, the increase in sodium and chloride excretion was much greater than that usually observed after aminophyllin alone. Similar enhancement of mercurial response was observed in previously resistant patients, J. B., E. S., and A. B., in whom both filtration rates and renal plasma flows rose following injections of aminophyllin (Table II).
In several patients (C. R., E. S., and A. B.), despite the improvement in renal hemodynamics after aminophyllin, even the augmented mercurial diuretic response was notably less than that of a typically responsive patient without aminophyllin. In these patients and B. G., who had virtually no diuretic response even after aminophyllin, serum sodium and chloride concentrations were significantly reduced (Table II).

Therefore, both renal hemodynamic functions and serum electrolyte concentrations were increased in subsequent studies on mercurial resistant subjects by infusions of 5 per cent sodium chloride, often with sufficient molar sodium lactate added to maintain the normal serum $\mathrm{Na} / \mathrm{Cl}$ ratio. In Table IV are presented observations made on patient E. S. six weeks after the previous study. During the control periods, his filtration rate, serum electrolyte concentrations, filtered electrolyte loads, and electrolyte excretion rates were still very much reduced. At the end of the 120-minute period during which $450 \mathrm{mEq}$. of 4.5 per cent sodium chloride solution were administered, there was no significant change in sodium and chloride excretion despite the increases in glomerular filtration rate, serum electrolyte concentrations, and filtered electrolytes. Then, the concentrated salt infusion was replaced by the previous mannitol-PAH infusion and $2 \mathrm{ml}$. of Mercuzanthin were administered intravenously. Seventy minutes later, when the filtered electrolyte loads were still greatly increased, there was maximal mercurial diuresis with urinary sodium and chloride excretions of 1.22 and $1.43 \mathrm{mEq} . / \mathrm{min}$., respectively, and a urine volume of $12.5 \mathrm{ml} . / \mathrm{min}$. After the peak diuresis, as the filtration rate and filtered electrolyte load began to decline, excretion 
of sodium, chloride, and water decreased too, despite maintenance of the serum sodium level.

Such intravenous administration of a concentrated salt solution for two hours prior to mercurial administration conceivably might have influenced the apparent natriuretic and diuretic response to the mercurial by affecting some mechanisms for base conservation, thereby independently decreasing tubular reabsorption of sodium. However, as demonstrated by the data on patient $\mathrm{E}$. S. (Table IV), there usually is no significant increase in electrolyte excretion during the early periods of concentrated salt infusion in patients in congestive failure without organic renal disease, maintained on low salt diets $(1,10)$. Therefore, experiments were performed in which the filtered loads of sodium and chloride were increased acutely by the injection of concentrated sodium solutions 60 to 90 minutes after giving the mercurial, when maximal mercurial depression of tubular activity generally has been achieved. For example, patient G. R., despite a moderate reduction in filtration rate and serum electrolyte concentrations, exhibited an adequate diuretic response to a $2 \mathrm{ml}$. intravenous injection of Mercuzanthin (Table V). As the effect of the mercurial waned and the filtration rate declined, urinary excretion of electrolyte and water decreased. At this point, when a balanced mixture of 5 per cent sodium chloride and molar sodium lactate was infused, there were prompt increases in renal plasma flow, filtration rate, serum electrolyte levels, and a simultaneous rise in urinary $\mathrm{Na}$ and $\mathrm{Cl}$ excretions, which finally were 50 per cent greater than following the mercurial alone. This urinary reflection of the improved renal hemodynamics and increased load of filtered electrolyte occurred much earlier than the usual renal response to acutely induced hypernatremia.

Similar results were obtained in patient A. R. whose diuretic response, 60 to 95 minutes after a mercurial, was only moderate (Table IV) until a 5 per cent sodium chloride infusion was given at a rate of $5 \mathrm{ml} . / \mathrm{min}$. During this infusion, which was associated with some increase in filtration rate, a greater increase in renal plasma flow, and a $15 \mathrm{mEq}$./1. increase in serum sodium concentration, there was a progressive rise in urinary sodium excretion to a value more than three times the previous post-mercurial maximum. However, in this patient, who had arteriosclerotic heart disease and possibly organic renal pathology, the continued increase may represent, in part, a secondary but independent effect of the concentrated salt infusion on urinary electrolyte excretion.

The same procedure was attempted in patient

TABLE IV

Effect of concentrated sodium infusions on the diuretic response of cardiac patients to Mercuzanthin

\begin{tabular}{|c|c|c|c|c|c|c|c|c|c|c|c|}
\hline Patient & Period & Time & R.P.F. & G.F.R. & $\begin{array}{c}\text { Serum } \\
\mathrm{Na}\end{array}$ & $\underset{\mathrm{Cl}}{\operatorname{Serum}}$ & $\begin{array}{l}\mathrm{Na} \\
\text { filt. }\end{array}$ & $\underset{\text { excr. }}{\mathrm{Na}}$ & $\underset{\text { filt. }}{\mathrm{Cl}}$ & $\underset{\text { excr. }}{\mathrm{Cl}}$ & $\begin{array}{l}\text { Urine } \\
\text { vol. }\end{array}$ \\
\hline \multirow[t]{3}{*}{ E. $S$. } & Control & $\begin{array}{l}\min . \\
0-53\end{array}$ & $\begin{array}{c}\text { ml. } / \text { min } \\
194\end{array}$ & $\underset{55}{m l . / m i n}$ & $\begin{array}{c}m E q . / l . \\
123\end{array}$ & $\begin{array}{c}m E q . / l . \\
89\end{array}$ & $\begin{array}{c}\text { mEq./min } \\
6.74\end{array}$ & $\begin{array}{c}m E q . / \min . \\
0.002\end{array}$ & $\begin{array}{c}m E q . / m i n \\
5.32\end{array}$ & $\begin{array}{c}m E q . / m i n \\
0.004\end{array}$ & $\begin{array}{c}\text { ml./min. } \\
1.97\end{array}$ \\
\hline & $5 \% \mathrm{NaCl}^{*}$ & $124-140$ & 192 & 62 & 139 & 107 & 8.60 & 0.006 & 7.32 & 0.018 & 1.25 \\
\hline & Mercuz. $†$ & $\begin{array}{l}194-204 \\
204-214 \\
214-227 \\
227-237 \\
237-246 \\
246-259\end{array}$ & $\begin{array}{l}194 \\
190 \\
187 \\
195 \\
188 \\
176\end{array}$ & $\begin{array}{l}82 \\
84 \\
75 \\
69 \\
67 \\
65\end{array}$ & $\begin{array}{l}136 \\
135 \\
135 \\
135 \\
135 \\
135\end{array}$ & $\begin{array}{l}107 \\
104 \\
103 \\
103 \\
102 \\
101\end{array}$ & $\begin{array}{c}11.1 \\
11.4 \\
10.2 \\
9.33 \\
9.07 \\
8.74\end{array}$ & $\begin{array}{l}1.13 \\
1.22 \\
0.998 \\
0.930 \\
0.854 \\
0.725\end{array}$ & $\begin{array}{l}9.74 \\
9.71 \\
8.55 \\
7.85 \\
7.56 \\
7.30\end{array}$ & $\begin{array}{l}1.44 \\
1.43 \\
1.29 \\
1.23 \\
1.14 \\
0.946\end{array}$ & $\begin{array}{c}12.1 \\
12.5 \\
11.4 \\
10.7 \\
10.3 \\
8.88\end{array}$ \\
\hline \multirow[t]{3}{*}{ A. $\mathbf{R}$. } & Control & $0-48$ & 195 & 62 & 126 & 95 & 7.89 & 0.059 & 6.55 & 0.141 & 4.80 \\
\hline & Mercuz. $\ddagger$ & $138-150$ & 191 & 54 & 125 & 95 & 7.28 & 0.445 & 5.70 & 0.710 & 8.89 \\
\hline & Conc. $\mathrm{Na}$ Inf. 8 & $\begin{array}{l}178-188 \\
188-198 \\
198-208\end{array}$ & $\begin{array}{l}267 \\
264 \\
266\end{array}$ & $\begin{array}{l}59 \\
62 \\
62\end{array}$ & $\begin{array}{l}137 \\
138 \\
140\end{array}$ & $\begin{array}{l}102 \\
103 \\
106\end{array}$ & $\begin{array}{l}8.08 \\
8.50 \\
8.73\end{array}$ & $\begin{array}{l}1.19 \\
1.41 \\
1.60\end{array}$ & $\begin{array}{l}6.76 \\
7.05 \\
7.34\end{array}$ & $\begin{array}{l}1.53 \\
1.72 \\
1.93\end{array}$ & $\begin{array}{l}14.1 \\
15.5 \\
16.5\end{array}$ \\
\hline
\end{tabular}

* $5 \% \mathrm{NaCl}$ infused I.V. at $4.5 \mathrm{ml}$./min. from minutes 53 to 173 .

† Mercuzanthin $2 \mathrm{ml}$. I.V. at minutes 145-146.

Mercuzanthin $2 \mathrm{ml}$. I.V. at minutes 55-57.

$\$ 5 \% \mathrm{NaCl}(550 \mathrm{ml}$.) + Molar Na Lactate (80 cc.) infused I.V. at $5 \mathrm{ml} . / \mathrm{min}$. from minutes 161 to 208. 
RESPONSE TO MERCURIAL DIURETICS IN CONGESTIVE FAILURE

TABLE $v$

Immediate effect of concentrated sodium infusion on mercurial diuresis in chronic congestive failure

\begin{tabular}{|c|c|c|c|c|c|c|c|c|c|c|}
\hline Patient & Period & R.P.F. & G.F.R. & $\underset{\mathbf{N a}}{\text { Serum }}$ & $\underset{\mathrm{Cl}}{\text { Serum }}$ & $\begin{array}{l}\mathrm{Na} \\
\text { filt. }\end{array}$ & $\underset{\text { excr. }}{\mathrm{Na}}$ & $\underset{\text { filt. }}{\mathrm{Cl}}$ & $\underset{\text { excr. }}{\mathrm{Cl}}$ & $\begin{array}{l}\text { Urine } \\
\text { vol. }\end{array}$ \\
\hline \multirow[t]{3}{*}{ B. G. } & Control & $\begin{array}{c}\text { ml. } / \text { mix. } \\
62\end{array}$ & $\begin{array}{c}\text { ml. } / \min . \\
21.8\end{array}$ & $\begin{array}{c}m E q . / l . \\
114\end{array}$ & $\begin{array}{c}m E q . / l . \\
82\end{array}$ & $\begin{array}{c}m E q . / \min . \\
2.48\end{array}$ & $\begin{array}{c}m E q . / m i n \\
0.001\end{array}$ & $\begin{array}{c}m E q . / \min . \\
1.79\end{array}$ & $\begin{array}{c}m E q . / m i n \\
0.000\end{array}$ & $\begin{array}{c}\text { ml. } / \min . \\
.09\end{array}$ \\
\hline & Mercuz. & 57 & 22.9 & 111 & 82 & 2.56 & 0.003 & 1.88 & 0.000 & 1.06 \\
\hline & $\begin{array}{l}5 \% \mathrm{NaCl}^{*} \\
\text { Stop Inf. }\end{array}$ & $\begin{array}{r}81 \\
97 \\
111 \\
111 \\
110 \\
113 \\
99 \\
100\end{array}$ & $\begin{array}{l}24.8 \\
27.3 \\
29.5 \\
29.5 \\
29.6 \\
30.3 \\
25.8 \\
24.5\end{array}$ & $\begin{array}{l}112 \\
115 \\
119 \\
122 \\
125 \\
126 \\
126 \\
125\end{array}$ & $\begin{array}{l}84 \\
86 \\
88 \\
92 \\
94 \\
95 \\
93 \\
91\end{array}$ & $\begin{array}{l}2.78 \\
3.13 \\
3.50 \\
3.62 \\
3.70 \\
3.83 \\
3.26 \\
3.06\end{array}$ & $\begin{array}{l}0.007 \\
0.040 \\
0.115 \\
0.204 \\
0.263 \\
0.309 \\
0.208 \\
0.121\end{array}$ & $\begin{array}{l}2.09 \\
2.60 \\
2.88 \\
3.02 \\
3.10 \\
3.20 \\
2.67 \\
2.47\end{array}$ & $\begin{array}{l}0.000 \\
0.192 \\
0.307 \\
0.410 \\
0.467 \\
0.528 \\
0.384 \\
0.292\end{array}$ & $\begin{array}{l}1.20 \\
2.56 \\
3.64 \\
4.57 \\
4.88 \\
5.18 \\
3.97 \\
3.18\end{array}$ \\
\hline \multirow[t]{3}{*}{ G. R. } & Control & 142 & 56.1 & 129 & 100 & 7.30 & 0.005 & 6.31 & 0.016 & 5.10 \\
\hline & Thiomerin & $\begin{array}{l}181 \\
166 \\
186 \\
175 \\
167 \\
154\end{array}$ & $\begin{array}{l}69.1 \\
67.2 \\
67.9 \\
65.7 \\
65.4 \\
61.4\end{array}$ & $\begin{array}{l}129 \\
129 \\
130 \\
130 \\
130 \\
130\end{array}$ & $\begin{array}{l}100 \\
101 \\
101 \\
101 \\
101 \\
101\end{array}$ & $\begin{array}{l}8.98 \\
8.76 \\
8.89 \\
8.65 \\
8.62 \\
8.10\end{array}$ & $\begin{array}{l}0.020 \\
0.021 \\
0.428 \\
0.823 \\
0.817 \\
0.723\end{array}$ & $\begin{array}{l}7.74 \\
7.53 \\
7.61 \\
7.46 \\
7.42 \\
7.00\end{array}$ & $\begin{array}{l}0.098 \\
0.087 \\
0.595 \\
1.08 \\
1.08 \\
0.995\end{array}$ & $\begin{array}{l}10.3 \\
8.81 \\
12.9 \\
14.5 \\
13.0 \\
11.0\end{array}$ \\
\hline & $5 \% \mathrm{NaCl} \dagger$ & $\begin{array}{l}170 \\
206 \\
219\end{array}$ & $\begin{array}{l}61.3 \\
66.3 \\
71.3\end{array}$ & $\begin{array}{l}134 \\
138 \\
139\end{array}$ & $\begin{array}{l}103 \\
105 \\
105\end{array}$ & $\begin{array}{l}8.27 \\
9.24 \\
9.99\end{array}$ & $\begin{array}{l}0.805 \\
1.11 \\
1.25\end{array}$ & $\begin{array}{l}7.07 \\
7.85 \\
8.42\end{array}$ & $\begin{array}{l}1.10 \\
1.37 \\
1.50\end{array}$ & $\begin{array}{l}11.1 \\
11.8 \\
13.4\end{array}$ \\
\hline
\end{tabular}

$* 5 \% \mathrm{NaCl}$ I.V. at $3 \mathrm{ml} . / \mathrm{min}$.

$+5 \% \mathrm{NaCl}$ I.V. at $6 \mathrm{ml}$./min.

B. G., who three weeks previously had exhibited little potentiation of mercurial diuresis after aminophyllin injection. In the interim, her cardiovascular status had rapidly deteriorated. Her filtration rate and renal plasma flow were about 60 per cent lower than before and her serum electrolyte concentrations were still very reduced (Table V). Again, a mercurial alone had no effect on urinary electrolyte excretions. However, two hours after injecting the mercurial, when 5 per cent saline solution was infused intravenously at $3 \mathrm{ml} . / \mathrm{min}$., sodium and chloride excretion immediately rose as renal plasma flow, filtration rate, and serum electrolyte concentrations increased. Urinary electrolyte excretion was greatest when the filtered sodium and chloride loads were maximal, but fell sharply and rapidly as filtration rate decreased after the concentrated salt infusion was stopped, despite the persistance of the increased renal plasma flow and serum electrolyte levels. However, with the severely impaired cardiovascular renal hemodynamics, the electrolyte diuresis did not approach that observed during a good mercurial response. It should be noted that when the concentrated salt infusion was given after the mercurial, good diuresis occurred at a filtered sodium load of $3.83 \mathrm{mEq} . / \mathrm{min}$., whereas little diuresis occurred at a sodium load of 8.29 $\mathrm{mEq}$./min. after a mercurial followed by aminophyllin (Table II). Apparently, a hypertonic saline infusion, in addition to increasing filtered load, affects still other mechanisms influencing mercurial diuresis.

The influence of a more rapid rate of infusion of concentrated salt solution was tested in patient M. M., who had the lowest serum electrolytes and most severely impaired renal hemodynamics encountered in our large series of cardiacs without renal disease (Table VI). Ninety-six minutes after intravenous injection of $2 \mathrm{ml}$. of Mercuzanthin, which had little diuretic effect, a concentrated sodium chloride-sodium lactate infusion was given at a rate of $8 \mathrm{ml} . / \mathrm{min}$. for the first ten minutes and, then, at a rate of $4 \mathrm{ml} . / \mathrm{min}$. until the end of the study. In the first fourteen-minute period after starting this infusion, there were marked increases in urinary electrolyte and water excretions, which persisted as the improvement in renal hemodynamics, serum electrolyte levels, and filtered electrolyte loads was maintained. After $40 \mathrm{~min}$ - 
TABLE VI

Augmentation of mercurial diuresis by administration of concentrated sodium infusion and aminophyllin to mercurial-resistant patient $M$. $M$.

\begin{tabular}{|c|c|c|c|c|c|c|c|c|c|c|}
\hline Period & Time & R.P.F. & G.F.R. & $\underset{\mathbf{N a}}{\text { Serum }}$ & $\underset{\mathrm{Cl}}{\text { Serum }}$ & $\begin{array}{l}\mathrm{Na} \\
\text { filt. }\end{array}$ & $\underset{\text { excr. }}{\mathrm{Na}}$ & $\begin{array}{c}\mathrm{Cl} \\
\text { filt. }\end{array}$ & $\underset{\text { excr. }}{\mathrm{Cl}}$ & $\begin{array}{l}\text { Urine } \\
\text { vol. }\end{array}$ \\
\hline Control & $\begin{array}{l}\min . \\
0-70\end{array}$ & $\underset{54.4}{m l . / m i n}$. & $\begin{array}{c}\text { ml. } / \min . \\
21.3\end{array}$ & $\begin{array}{l}m E q . / l . \\
107\end{array}$ & $\begin{array}{c}m E q . / l . \\
72.4\end{array}$ & $\begin{array}{c}m E q . / m i n \\
2.36\end{array}$ & $\begin{array}{c}\text { mEq./min. } \\
0.004\end{array}$ & $\begin{array}{c}m E q . / \min . \\
1.70\end{array}$ & $\begin{array}{c}m E q . / \min . \\
0.015\end{array}$ & $\begin{array}{c}\text { ml. } / \min . \\
1.66\end{array}$ \\
\hline Mercuz.* & $149-167$ & 57.6 & 20.8 & 103 & 72.9 & 2.13 & 0.014 & 1.66 & 0.042 & 2.62 \\
\hline \multirow[t]{2}{*}{ Conc. Na† } & $\begin{array}{l}167-180 \\
180-192\end{array}$ & $\begin{array}{l}86.4 \\
83.0\end{array}$ & $\begin{array}{l}29.1 \\
26.3\end{array}$ & $\begin{array}{l}113 \\
117\end{array}$ & $\begin{array}{l}79.4 \\
81.5\end{array}$ & $\begin{array}{l}3.26 \\
3.06\end{array}$ & $\begin{array}{l}0.232 \\
0.219\end{array}$ & $\begin{array}{l}2.54 \\
2.36\end{array}$ & $\begin{array}{l}0.276 \\
0.294\end{array}$ & $\begin{array}{l}6.62 \\
5.59\end{array}$ \\
\hline & $\begin{array}{l}192-205 \\
205-216\end{array}$ & $\begin{array}{l}83.5 \\
87.5\end{array}$ & $\begin{array}{l}26.9 \\
27.3\end{array}$ & $\begin{array}{l}117 \\
116\end{array}$ & $\begin{array}{l}81.9 \\
80.7\end{array}$ & $\begin{array}{l}3.02 \\
3.13\end{array}$ & $\begin{array}{l}0.215 \\
0.231\end{array}$ & $\begin{array}{l}2.38 \\
2.42\end{array}$ & $\begin{array}{l}0.298 \\
0.318\end{array}$ & $\begin{array}{l}5.57 \\
5.36\end{array}$ \\
\hline \multirow[t]{2}{*}{ Aminoph. } & $\begin{array}{l}216-225 \\
225-233\end{array}$ & $\begin{array}{r}132.0 \\
94.0\end{array}$ & $\begin{array}{l}36.1 \\
34.5\end{array}$ & $\begin{array}{l}114 \\
113\end{array}$ & $\begin{array}{l}79.5 \\
78.9\end{array}$ & $\begin{array}{l}4.10 \\
3.86\end{array}$ & $\begin{array}{l}0.806 \\
0.639\end{array}$ & $\begin{array}{l}3.21 \\
2.99\end{array}$ & $\begin{array}{l}0.817 \\
0.642\end{array}$ & $\begin{array}{l}12.6 \\
10.7\end{array}$ \\
\hline & 233-242 & 88.0 & 31.2 & 112 & 78.2 & 3.47 & 0.441 & 2.68 & 0.506 & 8.94 \\
\hline
\end{tabular}

* Mercuzanthin $2 \mathrm{ml}$. at minutes $=70$.

† $5 \% \mathrm{NaCl}(430 \mathrm{ml}$.) + Molar Na Lactate $(120 \mathrm{ml}$.) inf. I.V. at $8 \mathrm{ml} . / \mathrm{min}$. from minutes $=167-177$, and at $4 \mathrm{ml}$./ $\min$. from minutes $=177-242$.

$\ddagger 0.50 \mathrm{gm}$. I.V. from minutes $=211-216$.

utes, $0.5 \mathrm{gm}$. of aminophyllin were given intravenously. With the additional increases in renal plasma flow, filtration rate, and filtered electrolyte loads, there was a further prompt and marked increase in excretion of sodium, chloride and water followed by a decline during the next two periods as filtration rate and renal plasma flow began to fall. At peak diuresis, urine flow was $12.6 \mathrm{ml} . / \mathrm{min}$., and sodium and chloride excretions were 0.806 and $0.817 \mathrm{mEq} . / \mathrm{min}$., respectively.

\section{DISCUSSION}

The failure of cardiac patients to respond to mercurial diuretics probably is conditioned by many of the factors influencing salt and water retention in congestive failure. That one of these markedly impaired renal hemodynamics can affect response to these agents is clearly demonstrated by the present data. Thus, if filtration is severely depressed, the load of electrolyte delivered to otherwise normal tubules may be so reduced that there is a disproportionately much greater decrease in sodium and chloride excretion. As a result, despite the usual tubular inhibition, the reabsorptive capacity of the tubules may not be exceeded and little additional electrolyte or water will be excreted after a mercurial. In this series of mercurial-resistant patients, acute increases in renal plasma flow and filtration rate, experi- mentally induced after administering mercurials, were associated with significant augmentation of diuresis. When the serum electrolyte concentrations, and therefore the filtered loads of sodium and associated anions, were further elevated by giving hypertonic infusions of sodium salts, even greater immediate response to mercurials was achieved. Our preliminary report of this implied relationship between filtered electrolyte load and response to mercurial diuretics has been confirmed by the observations of Pitts and Duggan (11) on dogs and normal men.

Thus, the previous diuretic unresponsiveness of these patients was not due to tubular resistance to mercury. That renal tubular functions other than electrolyte reabsorption also are affected to the usual degree by mercurials in such a patient (M. L.) is illustrated by the 60 per cent decrease in $\mathrm{Tm}_{\mathrm{PAB}}$ without any change in water or chloride output (Table VII), produced by an injection of $2 \mathrm{ml}$. of Thiomerin.

\section{TABLE VII}

Effect of Thiomerin on $T \mathrm{~m}_{\mathrm{PAB}}$ and chloride excretion of mercurial-resistant patient in congestive failure

\begin{tabular}{l|c|c|c|c|c}
\hline \hline Period & G.F.R. & $\begin{array}{c}\text { Plasma } \\
\text { PAH }\end{array}$ & $T_{\text {mPAH }}$ & $\begin{array}{c}\text { Chloride } \\
\text { excretion }\end{array}$ & $\begin{array}{c}\text { Urine } \\
\text { volume }\end{array}$ \\
\hline Control & $\begin{array}{c}\text { ml./min. } \\
47.1\end{array}$ & $\begin{array}{c}\text { mgm./ml. } \\
0.600\end{array}$ & $\begin{array}{c}\text { mgm./min. } \\
79.6\end{array}$ & $\begin{array}{c}\text { mEq./min. } \\
.002\end{array}$ & $\begin{array}{c}\text { ml. } / \text { min. } \\
3.05\end{array}$ \\
\hline Merc. & 32.0 & 0.923 & 32.0 & .026 & 3.80 \\
\hline
\end{tabular}


TABLE VIII

Effect of pre-treatment with desoxycorticosterone acetate* on mercurial diuresis in patient G. R. $\dagger$

\begin{tabular}{|c|c|c|c|c|c|c|c|c|c|}
\hline Period & R.P.F. & G.F.R. & $\underset{\mathbf{N a}}{\text { Serum }}$ & $\underset{\mathrm{Cl}}{\text { Serum }}$ & $\begin{array}{l}\mathrm{Na} \\
\text { filt. }\end{array}$ & $\begin{array}{c}\mathrm{Na} \\
\text { excr. }\end{array}$ & $\begin{array}{c}\mathrm{Cl} \\
\text { filt. }\end{array}$ & $\underset{\text { excr. }}{\mathrm{Cl}}$ & $\begin{array}{l}\text { Urine } \\
\text { vol. }\end{array}$ \\
\hline Control & $\begin{array}{c}\text { ml. } / \min . \\
175\end{array}$ & $\begin{array}{c}\text { ml. } / \text { min. } \\
59.4\end{array}$ & $\begin{array}{c}m E q . / l . \\
130\end{array}$ & $\begin{array}{c}m E q . / l . \\
93.6\end{array}$ & $\begin{array}{c}m E q . / m i n \\
7.84\end{array}$ & $\begin{array}{c}m E q . / \min \\
0.007\end{array}$ & $\begin{array}{c}m E q . / \min . \\
6.21\end{array}$ & $\begin{array}{c}m E q . / m i n \\
0.011\end{array}$ & $\begin{array}{r}m l . / \min \\
5.98\end{array}$ \\
\hline Thiomerin & $\begin{array}{l}164 \\
161 \\
161 \\
150 \\
147 \\
148 \\
156 \\
150 \\
154\end{array}$ & $\begin{array}{l}60.5 \\
60.6 \\
59.4 \\
55.4 \\
52.1 \\
53.6 \\
54.6 \\
53.1 \\
54.2\end{array}$ & $\begin{array}{l}129 \\
129 \\
130 \\
130 \\
130 \\
130 \\
130 \\
129 \\
129\end{array}$ & $\begin{array}{l}93.4 \\
94.1 \\
94.9 \\
94.7 \\
94.6 \\
93.9 \\
92.7 \\
91.9 \\
91.0\end{array}$ & $\begin{array}{l}7.84 \\
7.87 \\
7.73 \\
7.20 \\
6.78 \\
7.00 \\
7.11 \\
6.91 \\
7.01\end{array}$ & $\begin{array}{l}0.011 \\
0.009 \\
0.011 \\
0.015 \\
0.031 \\
0.071 \\
0.143 \\
0.171 \\
0.273\end{array}$ & $\begin{array}{l}6.29 \\
6.36 \\
6.28 \\
5.84 \\
5.49 \\
5.60 \\
5.64 \\
5.44 \\
5.51\end{array}$ & $\begin{array}{l}0.009 \\
0.016 \\
0.023 \\
0.035 \\
0.061 \\
0.125 \\
0.229 \\
0.268 \\
0.402\end{array}$ & $\begin{array}{r}7.23 \\
7.29 \\
6.63 \\
5.94 \\
5.79 \\
6.65 \\
8.25 \\
8.76 \\
10.6\end{array}$ \\
\hline
\end{tabular}

* 4 Doses of DCA (5 mgmq. 6 hours).

† Cf. Table V.

It should be re-emphasized, however, that any factor promoting renal salt conservation will tend to antagonize mercurial diuretics. Thus, if tubular reabsorption of electrolyte is significantly enhanced by any mechanism, mercurial inhibition of reabsorption in one part of the tubule may produce much less diuresis because of greater transfer of electrolyte and water back into the blood, perhaps at some other tubular site. The inhibition of mercurial diuresis by a humoral factor, for example, is illustrated by a subsequent study on G. R. who was given the same dose of Thiomerin before and after receiving four $5 \mathrm{mgm}$. doses of desoxycorticosterone acetate (DCA) at 6-hour intervals in the previous 24-hour period (Table VIII). Before receiving DCA, she had achieved maximal diuresis with a urine volume of 14.5 $\mathrm{ml} . / \mathrm{min}$. and sodium and chloride excretion rates of 0.823 and $1.08 \mathrm{mEq} . / \mathrm{min}$., respectively, within an hour (Table V). Eight days later, after receiving the desoxycorticosterone acetate, her body weight, clinical condition, and serum sodium levels were unchanged and her serum chloride level, filtration rate, and renal plasma flow were slightly lower. Now, one hour after receiving the mercurial, her sodium and chloride excretion rates were only 0.0107 and $0.0234 \mathrm{mEq} . / \mathrm{min}$., respectively. In the next hour, electrolyte and water excretions gradually increased, but never equalled the levels reached before DCA administration. Others have observed that, by administration of DCA or ACTH (12), inhibition of mercurial activity may be produced, which varies in degree de- pending upon the duration and intensity of treatment and other factors.

Such humoral influences on tubular reabsorption may have contributed to the gradually developing failure of response to mercurials observed in patient $\mathrm{J}$. B. during the severe salt restriction of the rice diet, which may lead to increased adrenal cortical activity as well as to altered renal hemodynamics (8). Yet the latter must also have played a role in view of the augmentation of mercurial diuresis observed when filtration rate and renal flow were increased by aminophyllin.

The activation of other sodium-conserving mechanisms in congestive failure may explain certain other well documented aspects of mercurial diuresis. A number of investigators $(1,2,13)$ have confirmed the early observations of Blumgart and his co-workers $(14,15)$ that during mercurial diuresis not only may relatively more chloride than sodium frequently be excreted but also potassium excretion may be increased in patients exhibiting sodium retention. The explanation for these phenomena may be the same: namely, that the kidney can actively conserve sodium without chloride by tubular transport of potassium, ammonia, and hydrogen. When the body responds to a stimulus leading to sodium retention, as in congestive failure, these ion exchange mechanisms probably are also stimulated. As a consequence, sodium that has escaped reabsorption because of mercurial depression of one tubular activity may be actively exchanged for other cations by distal tubular processes which may be less 
TABLE IX

Effect of pre-treatment with desoxycorticosterone acetate $(D C A)^{*}$ on mercurial diuresis in patient G. Re.

\begin{tabular}{|c|c|c|c|c|c|c|c|c|c|}
\hline & \multirow{2}{*}{ Period } & \multirow{2}{*}{ Time } & \multirow{2}{*}{$\begin{array}{l}\text { Urine } \\
\text { vol. }\end{array}$} & \multicolumn{3}{|c|}{ Urinary electrolyte excr. } & \multicolumn{3}{|c|}{ Serum electrolytes } \\
\hline & & & & $\mathrm{Na}$ & $\mathrm{Cl}$ & $\mathbf{K}$ & $\mathrm{Na}$ & $\mathbf{C l}$ & $\mathbf{K}$ \\
\hline \multirow{2}{*}{$\begin{array}{c}\text { Before } \\
\text { DCA }\end{array}$} & Control & ${ }_{100-0}^{\min .}$ & $\begin{array}{c}\text { ml./min. } \\
1.70\end{array}$ & $\begin{array}{c}\text { mEq./min. } \\
0.005\end{array}$ & $\begin{array}{c}m E q . / \min \\
0.004\end{array}$ & $\begin{array}{c}m E q . / \min . \\
0.030\end{array}$ & $\begin{array}{c}m E q . / l . \\
138\end{array}$ & $\begin{array}{c}m E q . / l . \\
102\end{array}$ & $\begin{array}{c}m E q . / . \\
5.40\end{array}$ \\
\hline & Thiomerint & $\begin{array}{c}0-30 \\
30-60 \\
60-90 \\
90-152 \\
152-182 \\
182-240\end{array}$ & $\begin{array}{l}1.90 \\
3.17 \\
5.83 \\
2.93 \\
2.38 \\
2.82\end{array}$ & $\begin{array}{l}0.012 \\
0.187 \\
0.432 \\
0.320 \\
0.266 \\
0.233\end{array}$ & $\begin{array}{l}0.021 \\
0.200 \\
0.478 \\
0.363 \\
0.301 \\
0.307\end{array}$ & $\begin{array}{l}0.024 \\
0.036 \\
0.057 \\
0.051 \\
0.047 \\
0.046\end{array}$ & 138 & 101 & 4.87 \\
\hline \multirow{2}{*}{$\begin{array}{l}\text { After } \\
\text { DCA }\end{array}$} & Control & $91-0$ & 3.10 & 0.004 & 0.014 & 0.047 & 139 & 106 & 5.63 \\
\hline & Thiomerin $\dagger$ & $\begin{array}{c}0-30 \\
30-60 \\
60-90 \\
90-150 \\
150-180 \\
180-240\end{array}$ & $\begin{array}{l}3.90 \\
4.14 \\
5.23 \\
3.22 \\
2.10 \\
1.52\end{array}$ & $\begin{array}{l}0.040 \\
0.217 \\
0.334 \\
0.218 \\
0.176 \\
0.099\end{array}$ & $\begin{array}{l}0.048 \\
0.281 \\
0.449 \\
0.332 \\
0.292 \\
0.196\end{array}$ & $\begin{array}{l}0.049 \\
0.060 \\
0.092 \\
0.106 \\
0.112 \\
0.092\end{array}$ & 139 & 105 & 4.50 \\
\hline
\end{tabular}

* $20 \mathrm{mgm}$. of DCA/day for 4 days.

$\dagger 2 \mathrm{ml}$. of Thiomerin.

affected by therapeutic doses of mercurials (16). Since these ion exchange mechanisms function to conserve sodium without chloride during mercurial diuresis, there may be an increase in urinary potassium, ammonia, and titratable acidity and a greater excretion of chloride than of sodium.

This possibility is illustrated by the data obtained on G. Re. before and immediately after four daily injections of $20 \mathrm{mgm}$. of desoxycorticosterone acetate (Table IX). The more prolonged administration of DCA to this rheumatic cardiac who was maintained on a low salt diet, did not abolish the diuretic response but did lead to increased potassium diuresis and a significant reduction in the excretion of sodium relative to chloride. Before DCA treatment, the cumulative chloride, sodium, and potassium excretions in the 240 minutes after administering the mercurial were $70.4,60.3$, and $10.8 \mathrm{mEq}$., respectively. After giving DCA, the chloride, sodium and potassium excretions in the equivalent post-mercurial period were $63.8,41.9$, and $21.3, \mathrm{mEq}$., respectively.

Titratable acidity and ammonia production also have been demonstrated to increase during mercurial diuresis in cardiac patients $(2,16)$. Since the sum of potassium, ammonium ion and titratable acid excretions tends to equal the excess of chloride over sodium excreted during the mercurial diuresis $(1,13)$, it would appear that ion ex- change mechanisms may be responsible for the reported discrepancy between urinary sodium and chloride as well as the increased potassium excretion. However, the primary diuretic action of the mercurial may well have been on tubular reabsorption of sodium and associated ions, as others have suggested (17).

In cardiac patients without organic renal disease, intensification of one or more of the factors promoting sodium retention in congestive failure -impaired cardiovascular-renal hemodynamics, elevated venous pressure, altered serum electrolytes, increased adrenal cortical activity, stimulation of volume receptors (18), and other variables $(4,5)$-may contribute to the development of mercurial resistance. Although, in this discussion, a correlation between increased filtered electrolyte load and augmentation of mercurial diuresis by administration of aminophyllin or concentrated salt solutions has been implied, it is recognized that either procedure may have also influenced other mechanisms affecting electrolyte excretion. Aminophyllin, for example, invariably produced an even greater increase in renal plasma flow in these patients (19), a circumstance which is often associated with improved electrolyte excretion in cardiac failure $(20,21,22)$. In patients in congestive failure, this drug may also produce a less persistent but significant increase in cardiac out- 
put and a decrease in venous pressure $(19,23)$ with consequent augmentation of sodium excretion, particularly when renal tubular reabsorption has already been depressed by a mercurial or perhaps by the aminophyllin itself $(24,25)$. Similarly, concentrated sodium infusions, in addition to producing the increases in filtered electrolyte load, may have influenced adrenal cortical, volume or renal mechanisms regulating electrolyte excretion. As in interpreting the role of those agents which potentiate mercurial diuresis, so in analyzing mercurial resistance per $s e$, it is futile to seek a single explanation applicable to all cases. In the individual patient, however, careful evaluation will often uncover the more important causal factors and thereby permit better therapy.

In the past five years, this approach to mercurial resistance has modified our treatment of patients who previously gave poor diuretic response to mercurials, even following pre-treatment with ammonium chloride. Effective mobilization of edema frequently has been achieved by the following procedure: 1) 6 to $9 \mathrm{gm}$. of ammonium chloride are given daily in divided doses for three days; 2) on the fourth day, $2 \mathrm{ml}$. of a mercurial are given; 3) two hours later, when maximal mercurial depression of tubular function is usually present, from 0.25 to $0.50 \mathrm{gm}$. of aminophyllin are injected intravenously over a period of 5 to 10 minutes. After receiving the mercurial, the patients are kept in bed until diuresis has subsided, since activity, which increases salt and water retention in congestive failure (24), also will tend to diminish the effect of mercurials. In patients who have been almost totally unresponsive to mercurials, profuse diuresis with marked weight loss has resulted. However, to avoid reactions, especially in elderly subjects, the aminophyllin should be given very slowly and cautiously.

It should be emphasized that in the present studies infusions of hypertonic sodium solutions were given experimentally to improve both renal hemodynamics and serum electrolyte levels. This procedure generally is not therapeutically practical and may even be harmful except perhaps in the presence of the acute depletion hyponatremia, associated with vascular collapse and further impairment of renal function. Generally, the amounts of sodium required to improve diuretic response are so great that the net effect, despite better diu- resis, is salt retention, thirst, increased water intake, and more edema. In dilution hyponatremia, hypertonic saline is contra-indicated.

\section{SUM MARY}

The ultimate failure of cardiac patients to respond to mercurial diuretics has been re-investigated as a phenomenon of renal electrolyte dysfunction in advanced heart failure.

In mercurial-resistant patients, the increased diuretic response achieved by injecting 0.48 to $0.72 \mathrm{gm}$. of theophylline ethylenediamine (aminophyllin) intravenously, 90 to 120 minutes after administering a mercurial, was much greater than that observed following aminophyllin alone, and was associated with an increase in the severely impaired renal plasma flow, filtration rate, and filtered load of electrolytes. In patients with reduced serum sodium and chloride concentrations, there was less augmentation of mercurial diuresis following aminophyllin administration. In such patients, acute increase of the serum electrolyte levels by infusion of concentrated sodium solutions intravenously, 90 to 120 minutes after giving a mercurial, resulted in an immediate increase in water, sodium, and chloride diuresis, which was much greater than the delayed diuresis following hypertonic salt infusions alone.

Although the improved response to mercurials in resistant patients following these procedures correlated well with the increase in filtered sodium and chloride loads, it is suggested that the diuretic response may have been influenced also by the concomitant changes in other factors which may affect tubular reabsorption of electrolyte. Thus, administration of desoxycorticosterone acetate in large doses for 24 hours was found to depress electrolyte diuretic response to a mercurial. Continuing such doses for four days before giving a mercurial resulted in greater decrease in sodium than chloride excretion with an equivalent in.crease in potassium excretion in a cardiac patient on a low salt diet. It is suggested 1) that adrenal cortical activity may also contribute to mercurial resistance by increasing tubular reabsorption of sodium; and 2) that the distal tubular ion exchange mechanisms for conserving sodium may be responsible for the increased potassium excretion and apparently greater chloruresis than natri- 
uresis observed after mercurials in many sodiumretaining patients.

It is concluded that the failure of cardiac patients to respond to mercurial diuretics results from the influence of the many factors promoting sodium retention in congestive failure.

\section{ACKNOWLEDGMENTS}

The authors wish to thank Miss Sybil Goldat, Mrs. Maidie Ross, and Mr. George Ross for their technical assistance.

\section{REFERENCES}

1. Stock, R. J., Mudge, G. H., and Nurnberg, M. J., Congestive heart failure. Variations in electrolyte metabolism with salt restriction and mercurial diuretics. Circulation, 1951, 4, 54.

2. Schwartz, W. B., and Wallace, W. M., Electrolyte equilibrium during mercurial diuresis. J. Clin. Invest., 1951, 30, 1089.

3. Hilton, J. G., Potentiation of diuretic action of mercuhydrin by ammonium chloride. J. Clin. Invest., 1951, 30, 1105.

4. Grossman, J., Weston, R. E., Halperin, J. P., and Leiter, L., The nature of the renal circulatory changes in chronic congestive failure as reflected by renal tubular maximal functions. J. Clin. Invest., 1950, 29, 1320.

5. Weston, R. E., Grossman, J., Escher, D. J. W., Mokotoff, R., and Leiter, L., Symposium on cardiovascular diseases. Pathogenesis and treatment of salt and water retention in congestive failure. M. Clin. North America, 1950, 34, 615.

6. Wesson, L. G., Jr., Anslow, W. P., Jr., and Smith, $H$. W., The excretion of strong electrolytes. Bull. New York Acad. Med., 1948, 24, 586.

7. Selkurt, E. E., Hall, P. W., and Spencer, M. P., Influence of graded arterial pressure decrement on renal clearance of creatinine, p-aminohippurate and sodium. Am. J. Physiol., 1949, 159, 369.

8. Weston, R. E., Hellman, L., Escher, D. J. W., Edelman, I. S., Grossman, J., and Leiter, L., Studies on the influence of the low sodium cardiac diet and the Kempner regimen on renal hemodynamics and electrolyte excretion in hypertensive subjects. J. Clin. Invest. 1950, 29, 639.

9. Berger, E. Y., Farber, S. J., and Earle, D. P., Jr., Renal excretion of mannitol. Proc. Soc. Exper. Biol. \& Med., 1947, 66, 62.

10. Futcher, P. H., and Schroeder, H. A., Studies on congestive heart failure. II. Impaired renal excretion of sodium chloride. Am. J. M. Sc., 1942, 204, 52.

11. Pitts, R. F., and Duggan, J. F., Studies on diuretics. II. The relationship between glomerular filtra- tion rate, proximal tubular absorption of sodium and diuretic efficacy of mercurials. J. Clin. Invest., 1950, 29, 372.

12. Axelrod, D. R., Alteration of diuretic response to Salyrgan by anoxia and ACTH. Federation Proc., 1951, 10, 7.

13. Lesser, G. T., Dunning, M. F., Epstein, F. H., and Berger, E. Y., Mercurial diuresis in edematous individuals. Circulation, 1952, 5, 85.

14. Blumgart, H. L., Gilligan, D. R., Levy, R. C., Brown, M. G., and Volk, M. C., Action of diuretic drugs. I. Action of diuretics in normal persons. Arch. Int. Med., 1934, 54, 40.

15. Blumgart, H. L., Gilligan, D. R., and Volk, M. C., Action of diuretic drugs. II. Effects of diuretic drugs on the acid-base equilibrium of the blood in patients with cardiac edema, in Medical papers dedicated to Henry Asbury Christian . . . Waverly Press, Baltimore, 1936, 191.

16. Weston, R. E., Grossman, J., and Leiter, L., The effect of mercurial diuretics on renal ammonia and titratable acidity production in acidotic human subjects with reference to site of diuretic action. J. Clin. Invest., 1951, 30, 1262.

17. Pitts, R. F., and Sartorius, O. W., Mechanism of action and therapeutic use of diuretics. Pharmacol. Rev., 1950, 2, 161; in J. Pharmacol. \& Exper. Therap., 1950, 98, Part II.

18. Peters, J. P., Sodium, water, and edema. J. Mt. Sinai Hosp., 1950, 17, 159.

19. Escher, D. J. W., Weston, R. E., Leiner, G., Leiter, L., and Goldat, S., The effect of Aminophyllin on cardiac output and renal hemodynamics in man. Federation Proc., 1948, 7, 31.

20. Brod, J., and Fejfar, Z., The origin of edema in heart failure. Quart. J. Med., 1950, 43, N.S. 19, 187.

21. Fishman, A. P., Maxwell, M. H., Crowder, C. H., and Morales, P., Kidney function in cor pulmonale. Particular consideration of changes in renal hemodynamics and sodium excretion during variation in level of oxygenation. Circulation, 1951, 3, 703.

22. Weston, R. E., and Grossman, J., Unpublished observations.

23. Howarth, S. McMichael, J., and Sharpey-Schafer, E. P., The circulatory action of theophylline ethylene diamine. Clin. Sc., 1947, 6, 125.

24. Sinclair-Smith, B., Kattus, A. A., Genest, J., and Newman, E. V., The renal mechanism of electrolyte excretion and metabolic balances of electrolytes and nitrogen in congestive heart failure; the effects of exercise, rest, and aminophyllin. Bull. Johns Hopkins Hosp., 1949, 84, 369.

25. Davis, J. O., and Shock, N. W., The effects of theophylline ethylene diamine on renal function in control subjects and in patients with congestive heart failure. J. Clin. Invest., 1949, 28, 1459. 